\title{
A STUDY OF TRACHEOTOMY AT ST JUSTINE'S HOSPITAL, MONTREAL
}

\section{H Turnier, M D , K Berdnikoff, M D, and Y Charest, M D}

HAVING LONG BEEN IMPRESSED by the importance in paediatrics of serious bronchopulmonary infections with grave and often fatal complications, we undertook a study of tracheotomy in these conditions Without doubt, tracheotomy has acquired an important place in paediatric anaesthesia $\mathrm{By}$ an evolution which has been slow but sure, tracheotomy has become well recognized as an essential part of the treatment of severe respiratocy difficulties The indications are well defined and the techniques used are $b_{a}$ sed on the fundamental principles of respiratory physiology ${ }^{2}$

This paper is a study of 52 cases of tracheotomy durng the period 1958 to 1960

Tracheotomy was found very effective and sometimes dramatic in its effects on children who were cyanosed or even at the stage of asphyxiation, with severe cyanosis and venous engorgement Tracheotomy also occupies an important place in paediatric surgery because, with its more frequent use, it has led to a better appreciation of pulmonary haemodynamics

Respiratory distress in children is such a dramatic condition, develops often so rapidly, and is fraught with such real danger, that we decided to review the subject, and to examme the case record" of the 52 tracheotomies performed at our hospital in the years 1958 to 1960

In going over the literature on respiratory distress one is immediately impressed by the vast range of material that is to be covered if one intends to be thorough We very rapidly gave in to the temptation to delve into only one of the facets of the subject, ie the manner in which respiratory distress could be helped by tracheotomy

Respiratory distress signifies respiratoly insufficiency This can occur at one of many levels Narrowing Reardon's ${ }^{20}$ classification and by order of frequency, these are $(a)$ external pulmonary level, where uptake of $\mathrm{O}_{2}$ and elimination of $\mathrm{CO}_{2}$ take place, $(b)$ between lungs and tissues, where transportation of $\mathrm{CO}_{2}$ and $\mathrm{O}_{2}$ takes place, $(c)$ internal respiration, where $\mathrm{O}_{2}$ and $\mathrm{CO}_{2}$ are utilized by tissue cells

It is fortunate that the second and thurd levels are found less frequently in paediatric practice, since less can be done as yet to correct any disorders arising from them Amongst those that can be cornected are the anaemias, in which raising the haemoglobin level improves $O_{2}$ transport

On the other hand many difficulties arise on the first level, that of the respiratory aurway, where the $\mathrm{O}_{2}-\mathrm{CO}_{2}$ exchanges take place These are far more obvious and are often more easily amenable to treatment Many authors have given classifications both of the disorders of respiration and of the evaluation of theil

Can Anaes Soc I, vol 11, no 6, November, 1964 
severity $\mathrm{H} \mathrm{Arey,}{ }^{4}$ for instance, breaks down the causes in the newborn infant to lesions of the central nervous system, pulmonary lesions, miscellaneous, such as congenital malformations of the heart, great vessels, paralysis of the phrenic nerve, diaphragmatic hernia, oesophageal atresia with fistula, and malformations of the lower jaw, epiglottis, or larynx It will be seen from our tables that we would add posterior choanal atresia as a relatively frequent cause An exicellent evaluation of the respiratory function of the newborn is given by $\mathrm{H} \mathrm{Miller,}{ }^{16}$ who suggests counting the respiratory rate in the first 48 hours and who considers a rise above $60 /$ minute as being a definite danger signal

Apgar's index is also well known, though more complicated ${ }^{3}$

Nelson, in his Textbook of Paedratrics, ${ }^{18}$ gives a classification of causes by chronological order (before, during, and after buth) in so far as the respiratory tract is concerned, and in anatomical order, from without inward, so to speak, and from above downward, starting with choanal atresia and ending with purely pulmonary lesions such at atelectasis and hyaline membranes

De Sanctis and Varga ${ }^{8}$ have simply made a classification of the main states in which a respiratory emergency may arise, especially since respiratory difficulties may stem from a multitude of causes in one and the same child Thus anything that tampers with the normal functioning of the central nervous system may produce (1) a change in the respiratory rhythm, which may go as far as complete arrest, (2) eventually a marked change in the acıd-base equilıbrum, and (3) a pooling of secretions in the trachea (thus causing a simple mechanical obstruction of the arrway)

Thus respiratory distiess through involvement of the C NS is due to at least three mechanisms and, when handling such a case, all three must be considered This adds also to the difficulties plaguing anyone who tries to classify these cases, and brings us back to our study of the cases of tracheotomies in our hospital In a purely arbitrary fashion three years were chosen (1958, 1959, and 1960, during which tracheotomies were perfoimed on 52 children

\section{INDICATIONS FOR TRACHIHOTOMY}

Tracheotomy is now being used widely as a deliberate method of treatment rather than as an emergency procedure ${ }^{14}$ With commoner recognition of the respiratory complications which may beset medical and surgical patients has come an increasing number of indications for the operation ${ }^{610,11,12}$ Tracheotomy has proved especially valuable in the prophylaxis and treatment of respiratory fallure, particularly when this arises as a consequence of retention of secretions or in relation to an operation The following is a tentative classification of conditions in which tracheotomy may be indicated '

(a) Obstruction of the upper arrway

Congenital anomalies

Trauma

Inflammation, acute and chronic

Neoplasms

Foreign bodies, paralysis

Extrunsic laryngeal diseases ${ }^{2}$ 
(b) Obstruction of the lower aurway

Among the most common lesions of the lower aurway are secretory obstruction and anomales producing compression of the trachea and oesophagus particularly tracheal stenosis and foreign bodies

(c) Primary neuromuscular disturbances

Pohomyelitss

'Tetanus

Botulism

Myasthenua.gravis

Bulbar or peripheral neurological lesibns

Severe debilitation and coma

(d) Mechancal interference with ventilation

Thoracic surgery

Multuple rib fractures

Persistent mediastunal emphvsema

(e) Systemic diseases

Generalized infections

Poisoning and toxic states

Cerebrovascular accidents

Severe trauma with bram mjunes

Neurosurgical procedures ${ }^{21}$

In general tracheotomy is indicated when in spite of good medical therapy respuratory obstruction progresses as evidenced by an increase in the respiratory

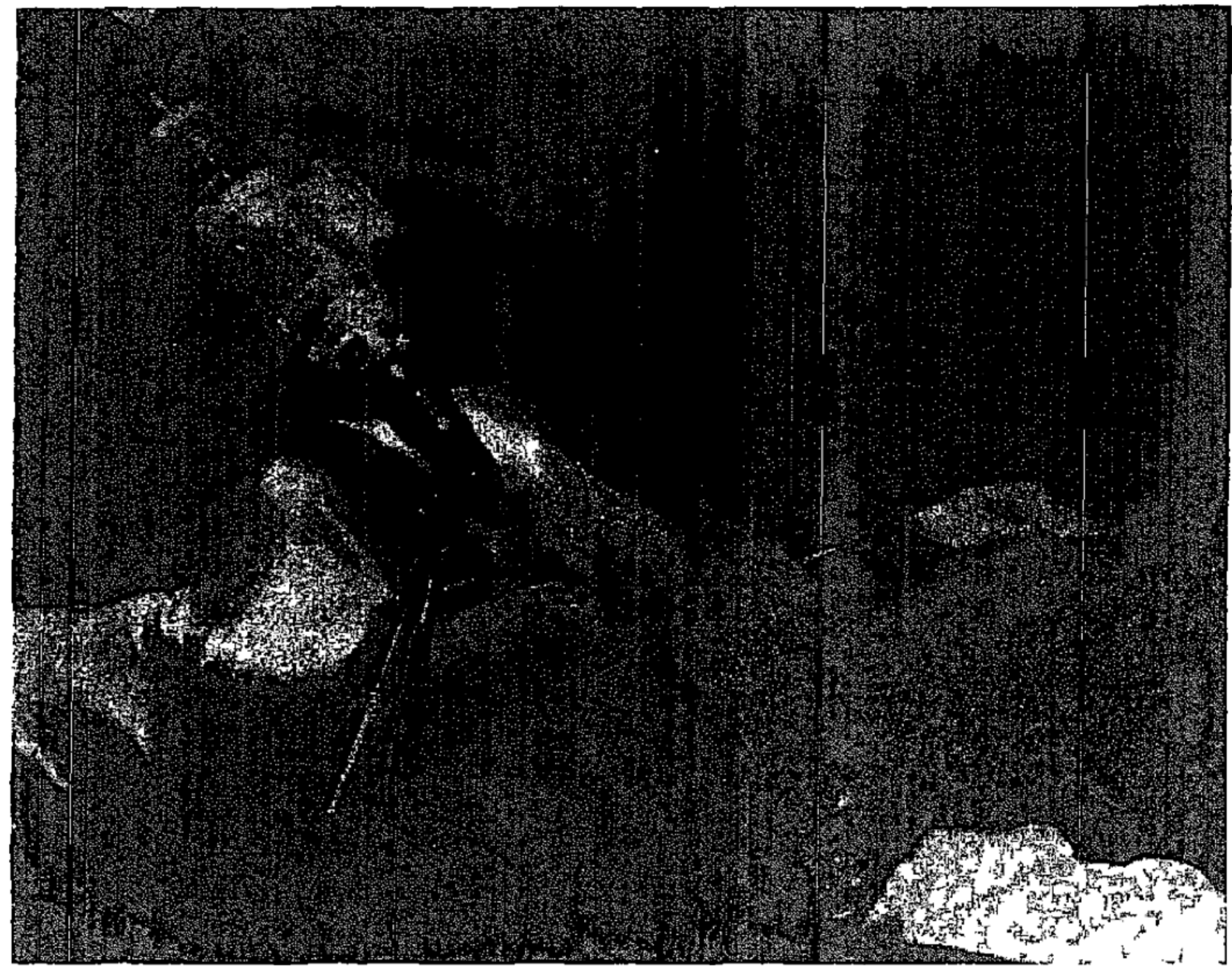

Figure 1 Approprat set up for tracheotomy 


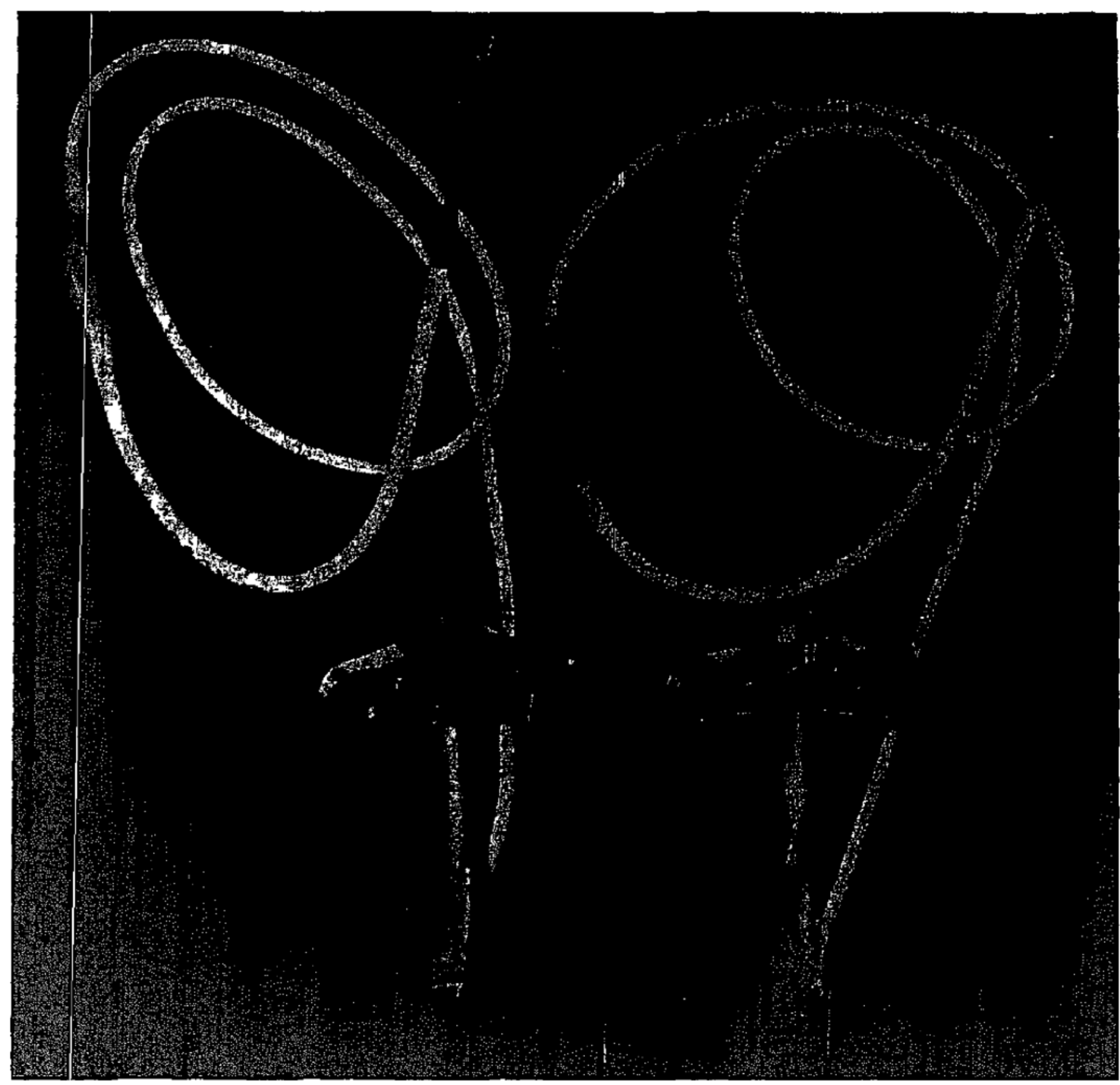

Fygure 2 Tracheotomy tube with cuff

rate in greater costal sternal and suprasternal indrawing and the increasing use of the accessory muscles when the heart rate continues to rise and remanns above 160 when the child becomes restless and apprehensive and when there is dimmishing air entry after a reasonable time of treatment Cyanosis and particu larly grey cyanosis is a grave sign and suggests heart falure ${ }^{10}$

\section{Discussion}

It is a well known fact that mechanical pioblems dommate the picture in infant respuratory physiology The following points bear witness to this fact

1 There is a small respiratory exchange which is very variable from one minute to the next and respiration is always Irregular in rhythm and amplitude

2 There 15 a small pulmonary capacity at this age

3 The larynx and major aurways are of narrow calbre and this explains the 


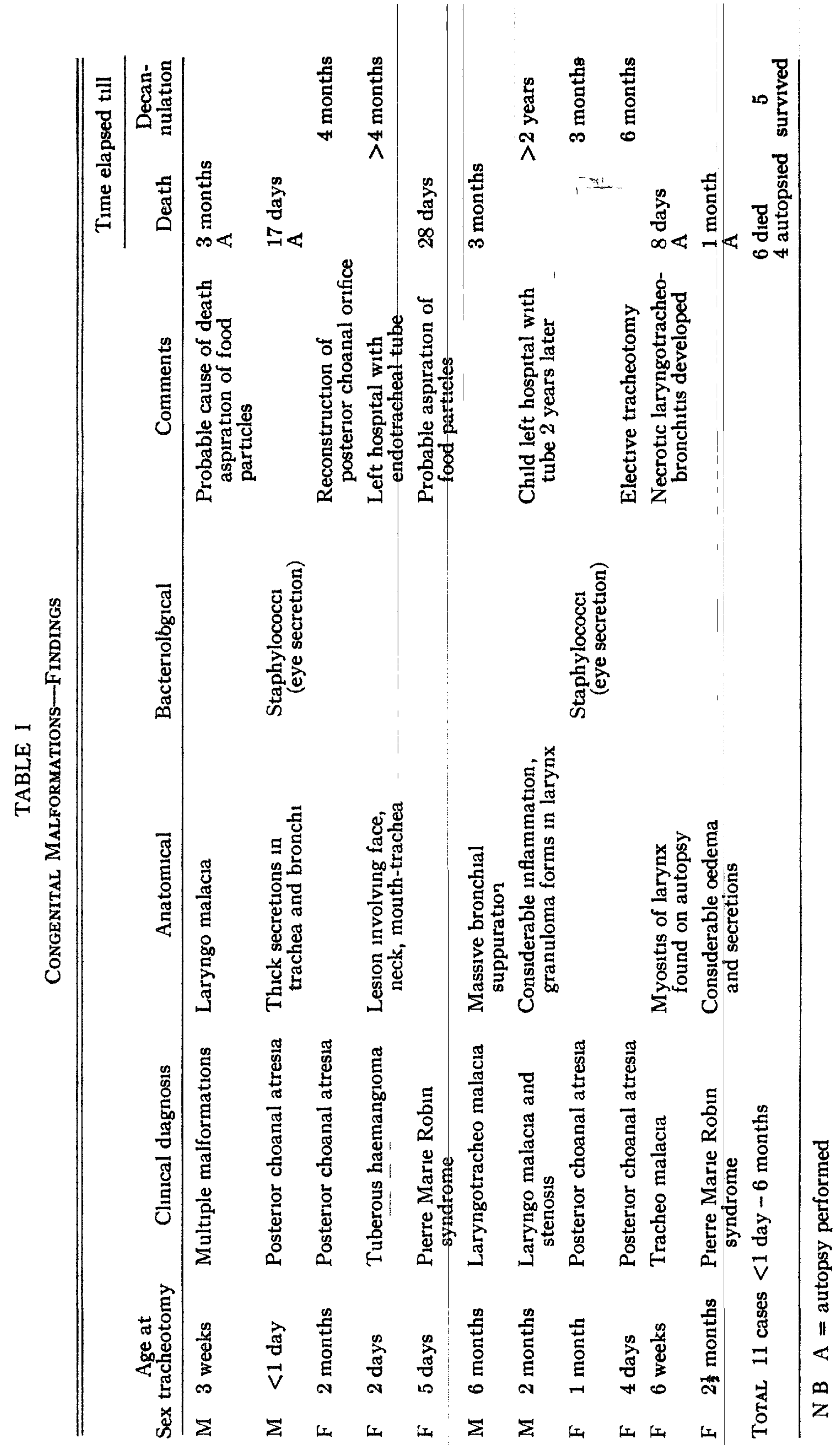




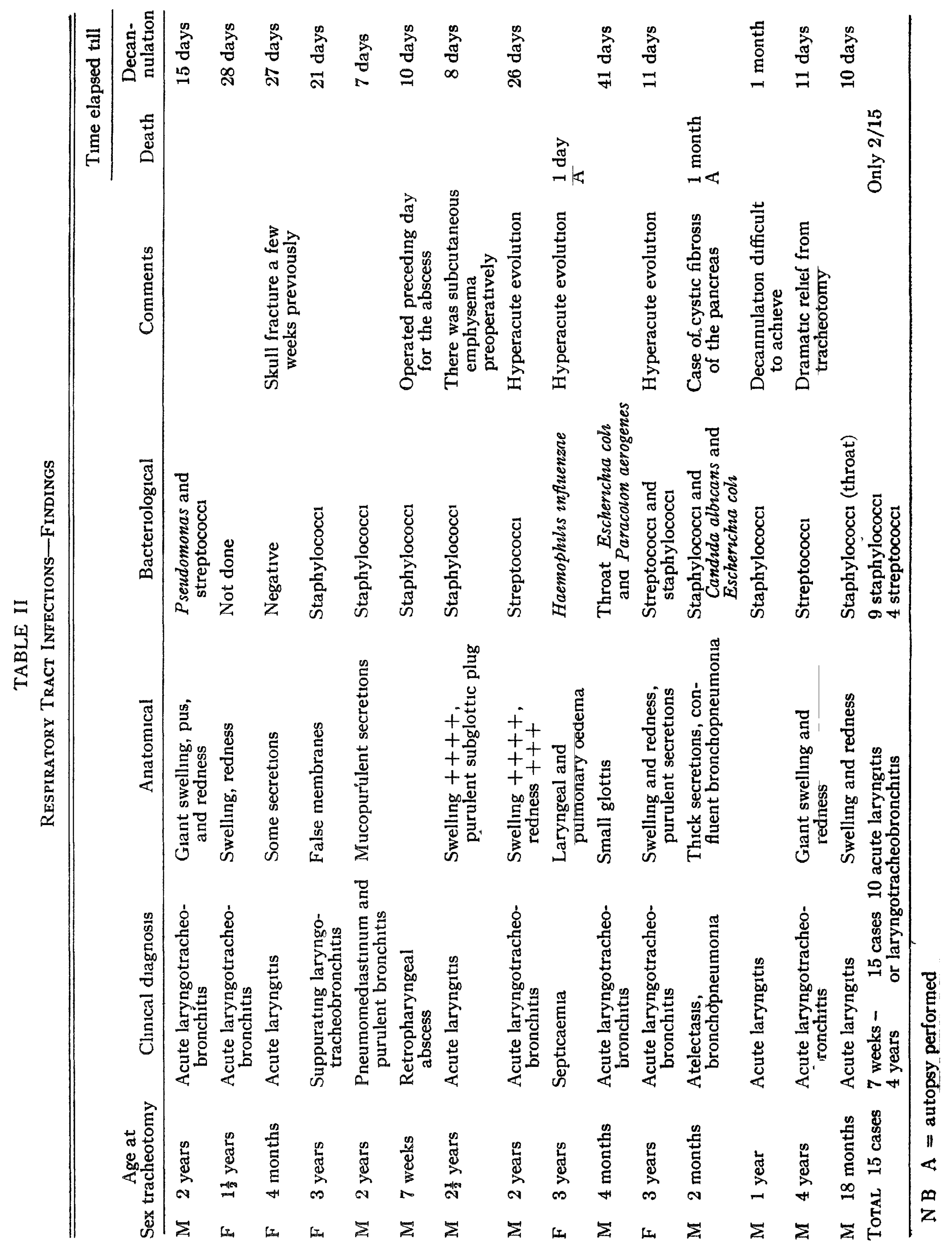




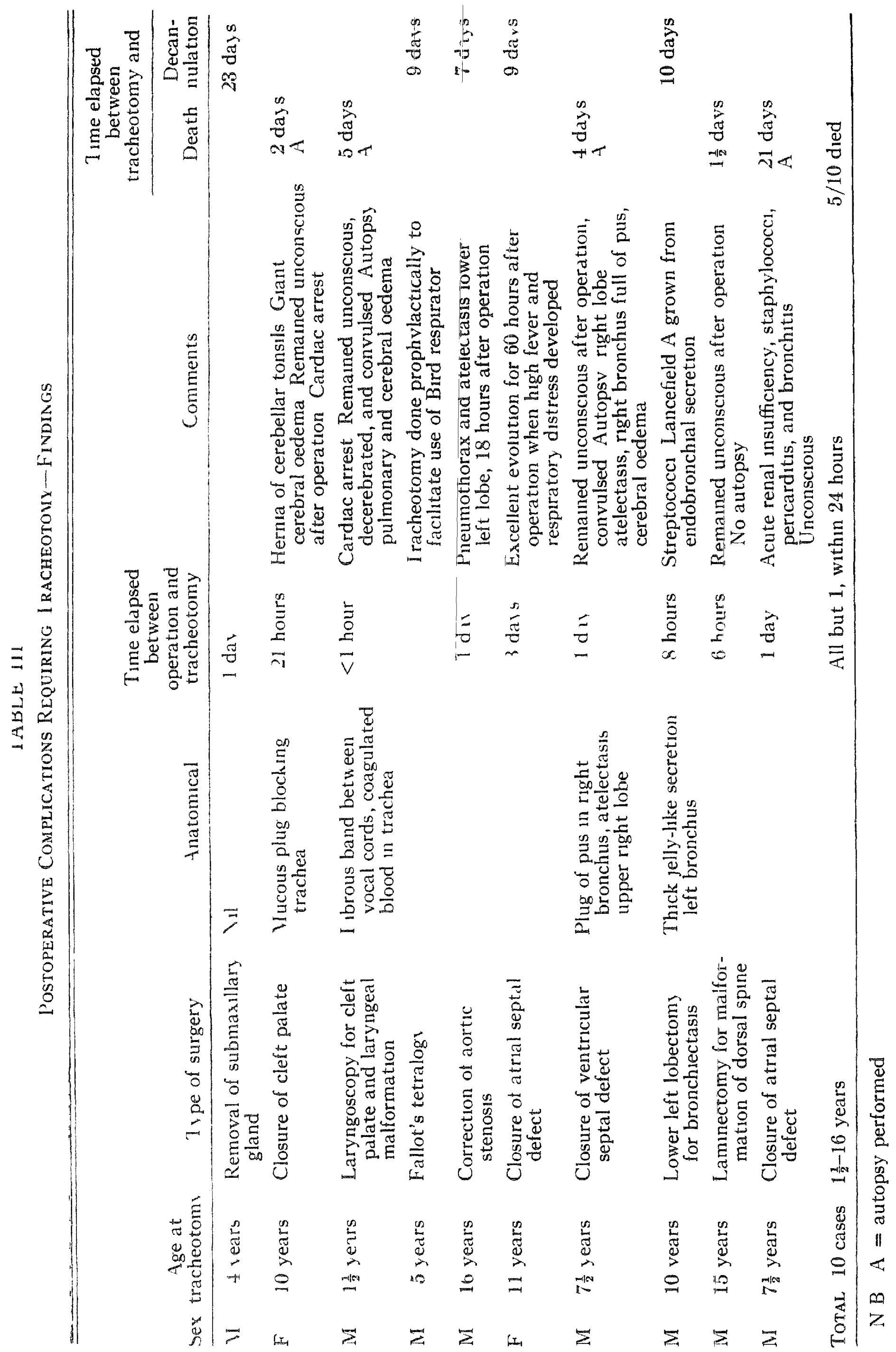




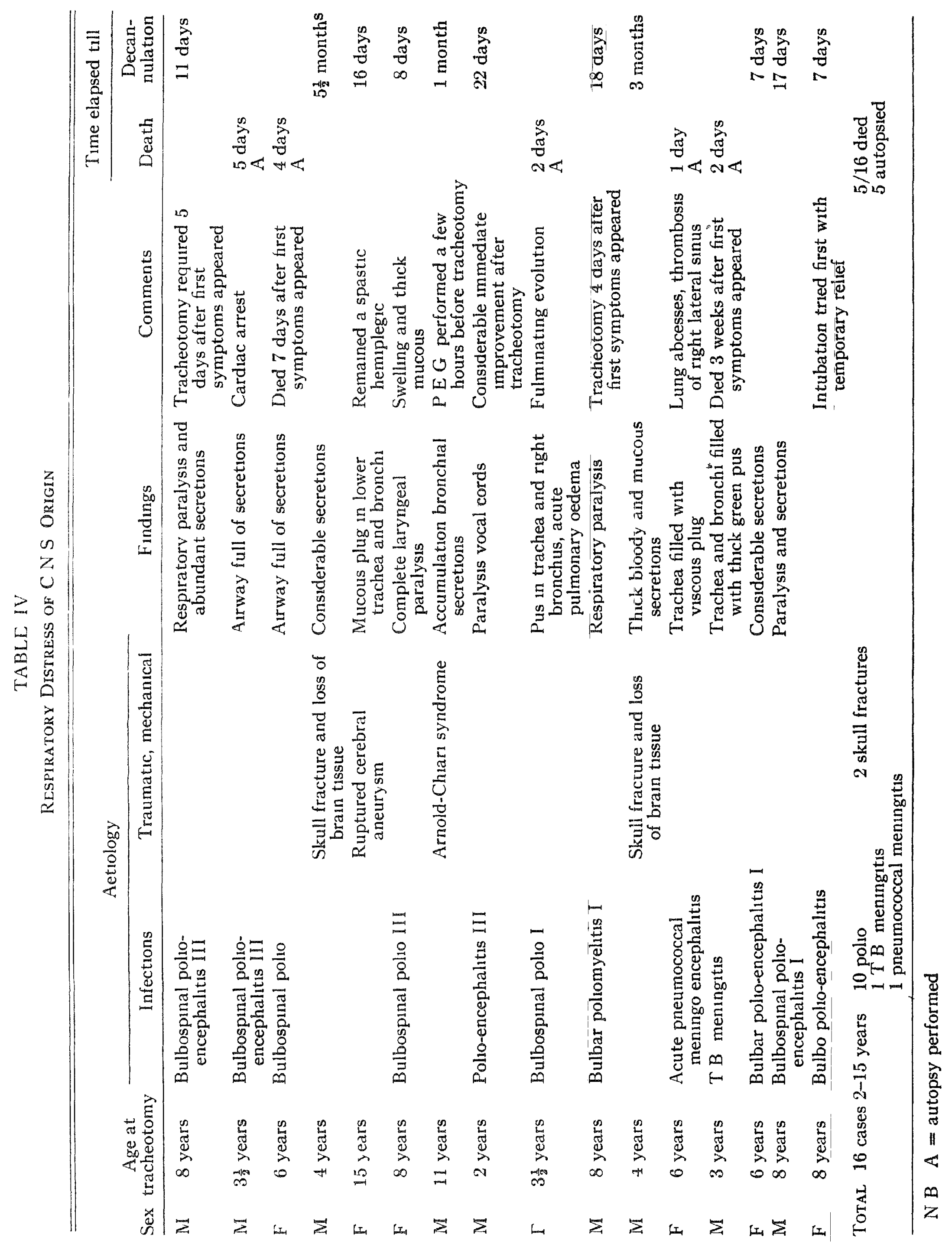


importance in the child of inflammatory states and episodes involving spasm at this level, and also the gravity of laryngeal lesions

4 Any increase in dead space is proportionately more serious in children than in adults because of the weaker thoracic and abdominal musculature ${ }^{22}$

Tracheotomy not only permits us to overcome an obstruction which is high up but enables us to use a mechanical re/ppirator more efficiently 'It also stimulates the pulmonary circulation and improves the ventilation and permits better oxygenation and elimination of $\mathrm{CO}_{2}$ The aspiration of bronchial secretions is also facilitated By reducing the dead space, the pulmonary ventılation is greatly improved and pulmonary exchange is accomplished with less mechanical work ${ }^{15}$

Tables I-IV show the principal calegories into which our 52 cases fall and give an analysis of the anatomical and bacteriological findings along with some general comments

Tracheotomy is a measure of extreme urgency on which the whole method of treating respiratory obstructions is built It is an operation of which the efficacy is universally recognized and whose frequency justifies a detailed study In paediatrics a different attitude is required towards tracheotony than in adults.

In adults, a small deviation from the normal respiratory pattern may be insignificant but, in a neonate or small child, the results of such a change can be disastrous

TRACHEOTOMY DURING RESPIRATORY INSUFFICIENCY

\begin{tabular}{lcccc}
\hline \hline & $\begin{array}{c}\text { Tidal } \\
\text { volume } \\
\text { (c c })\end{array}$ & $\begin{array}{c}\text { Tidal } \\
\text { Volume of } \\
\text { dead space } \\
\text { (c c })\end{array}$ & $\begin{array}{c}\text { Tidal } \\
\text { effective } \\
\text { volume } \\
\text { (c c })\end{array}$ & $\begin{array}{c}\text { alveolar } \\
\text { effective } \\
\text { volume } \\
(\%)\end{array}$ \\
\hline Before tracheotomy & 400 & 150 & 250 & 62 \\
After tracheotomy & 400 & 75 & 325 & 81 \\
Before tracheotomy & 300 & 150 & 150 & 50 \\
After tracheotomy & 300 & 75 & 225 & 75 \\
Before tracheotomy & 200 & 150 & 50 & 25 \\
After tracheotomy & 200 & 75 & 125 & 63 \\
\hline
\end{tabular}

\section{Postoperative Complications}

We have never been faced with a sudden death due to vasovagal reflexes or from sudden catastrophic haemorrhage

In our series we have picked out some cases of subcutaneous emphysema of the cervical tissues caused by a poor fit between the cannula and the tracheal opening The consequences were never serious

The obstruction of the cannula by sticky secretions may occur gradually and unnoticed, and suddenly cause a severe obstruction This we found to be a frequent problem and, when it happens, the clinical picture is always alarming because of the already nai row respiratory passages ${ }^{1}$

To avoid such a situation, it is necessary to have conscientious nursing with frequent observations of the colour of the face, lips, and extremities, and of the respiratory movements Nolsy respuration or tugging are premonitoly signs of respiratory difficulties ${ }^{7}$ 


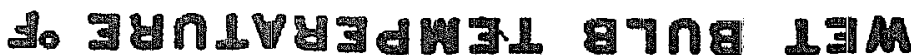

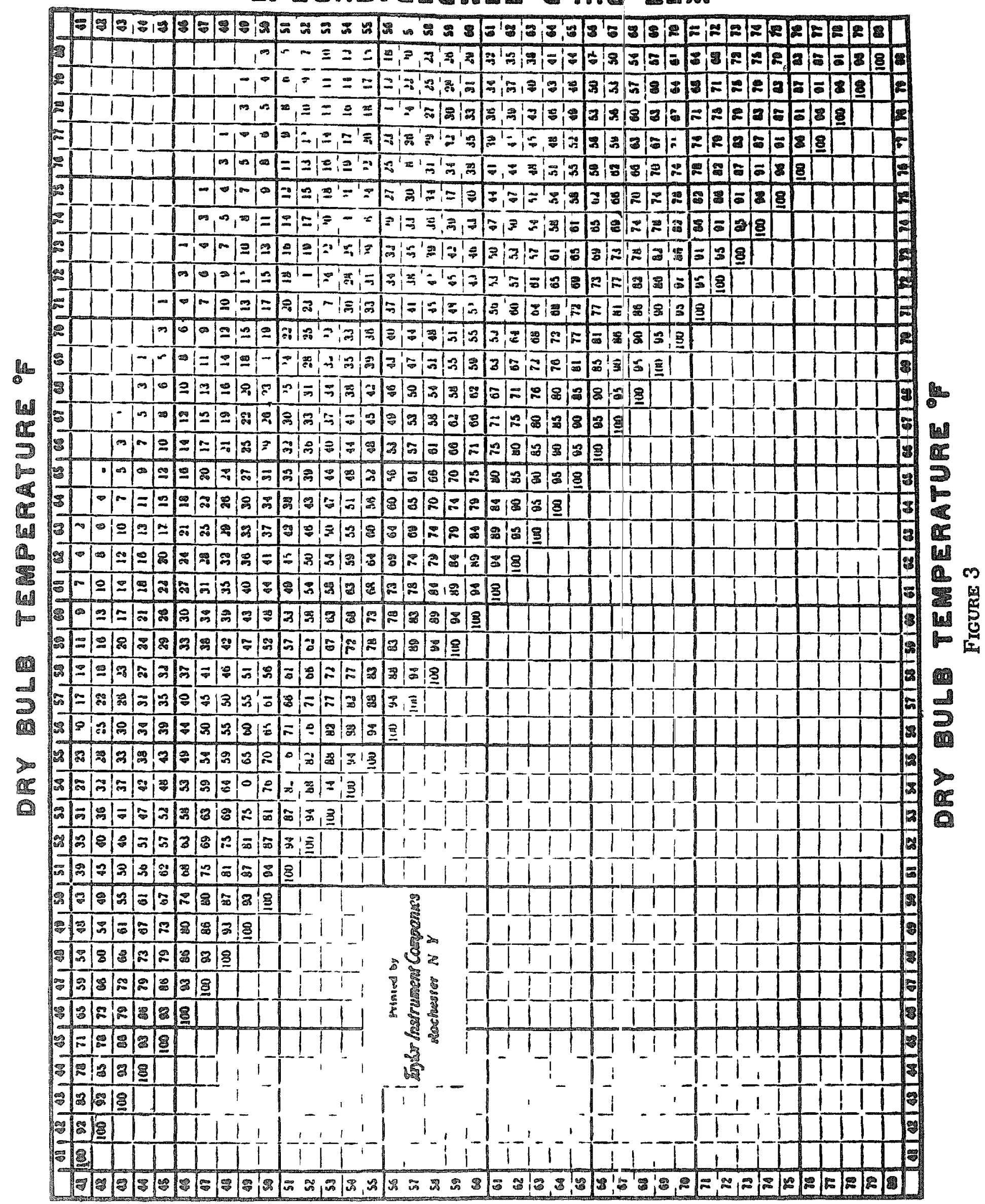




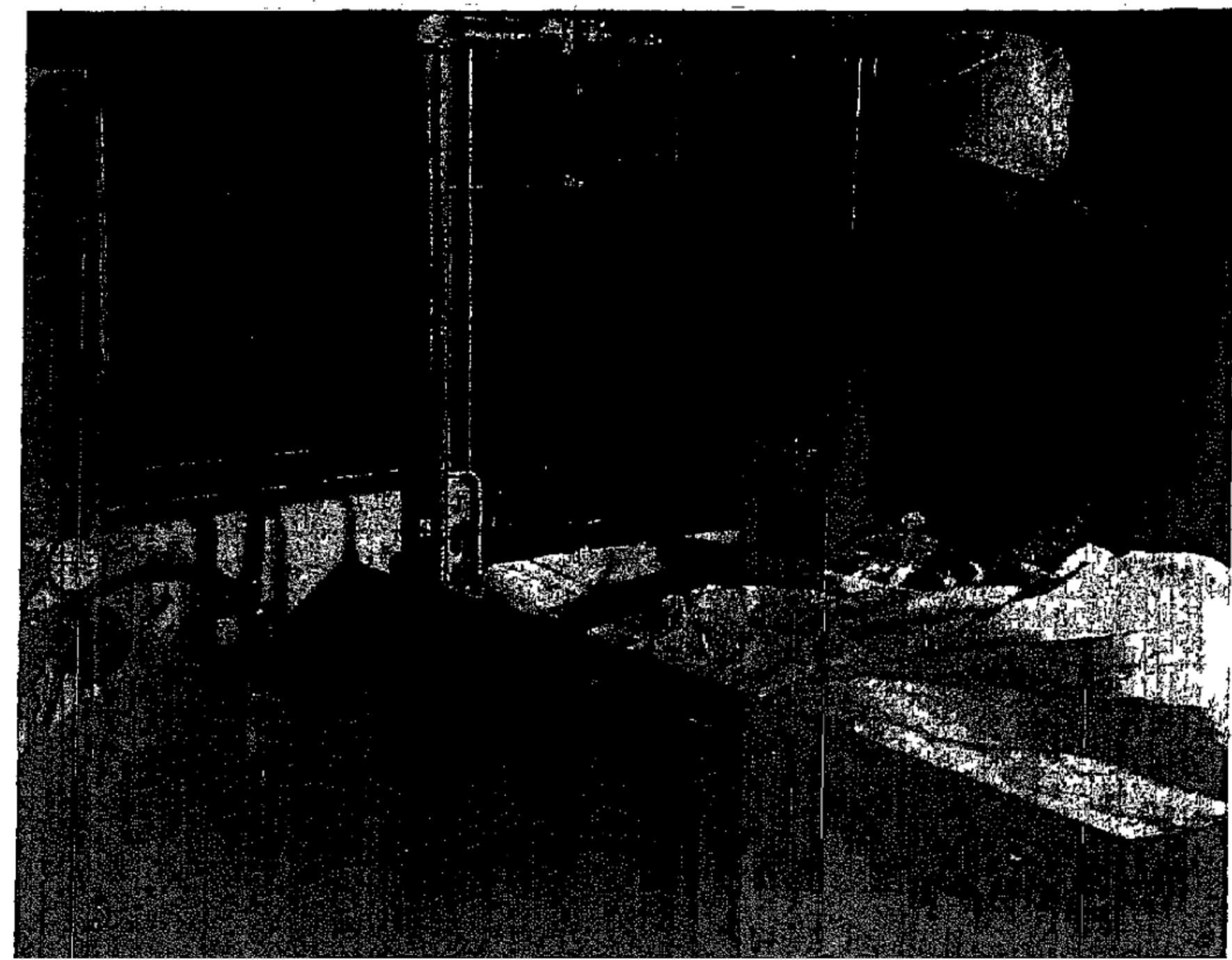

Froume 4 Humdifyng gadget used in the recovery room Tracheotomy mask shown in use with NCG No 24850 nebulizer and No 24681 corrugat $d \mathrm{t}$ bing

As can be seen from Table III 5 of the 10 cases had cardiac surgery performed for correction of septal defect aortic stenosis and Fallots tetralogy In one of these tracheotomy was done prophylactically Two other children died of what seemed to be cerebral damage o curring at some time during the operation as did' two others operated on for totdly different reasons one who underwent a laryngoscopy for cleft palate and associated laryngeal malformations and one who underwent a lammectomy of the dorsal spme which was deformed never regained consciousness after therr operations All four of these children became decerebrate and some had convulsions and all died a few hours to 5 days after the operation No clear cut cause for these deaths could be established Two of them had had abrupt cardiac standstill but heart action was resumed almost immediately in both cases

\section{Postopehatr E CaRe}

Close and constant care minmizes the complications considerably

A calm and competent nurse who can give sympathv and self confidence to the patient is a great help She must pay great attention to detal in keeping the arrway always clear by the systematic application of suction The tricheotomized patient has difficulty in expelling secretions

Good co operation from the child is needed 
Because the ay which enters the lungs does not pass throughi the nasal passages It is nether warmed nor filtered nor humidified by natural means Therefore the room temperature should be about $72-75$ Fahrenhert and the relative humidity sufficient to prevent irritation of the respiratory mucosa (90\%) At St Justine's we have high humidity rooms set up for this purpose ${ }^{19}$

The child will need a substantial calope intake which must be given in liquld form by a gavage tube untıl such tume as the oesophageal oedema wheh follows a tracheotomy has disappeared As the patients generat condition improves gradual additions can be made to this regimen untul the normal diet is attamed

The facies the character of the pulse and respiration and the temperature must be carefully watched

The tracheal cannula must constantly be $\mid$ kept free of secretions $\mid$ owing|to the complications which can result from a gradual accumulation in this site

\section{Conclusion}

In summary tracheotomy is a simple techmque although not without serious complications which renders invaluable service in many grave situations such as those of bronchial obstruction tracheal compression oedema of the larynx and paralysis of the respiratory muscles

Clinicians should be alert to its efficacy and reaay to apply|this measure without hesitation in a situation that demands it

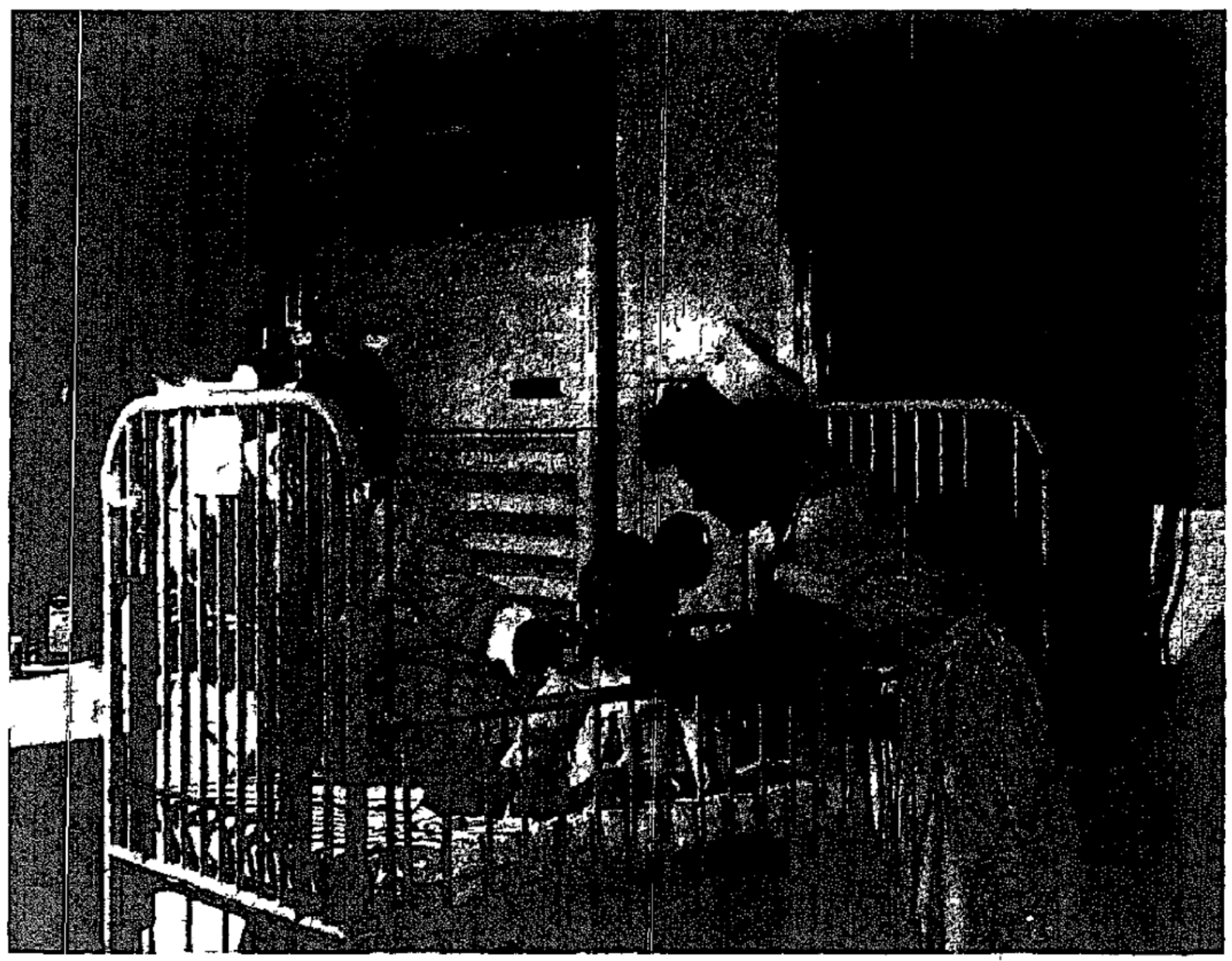

FigURE 5 Postoperative carel in high humidty room 


\section{RÉSUMÉ}

La détresse respiratorre chez les enfahts constitue un drame, elle s'installe sı rapidement et elle comporte un tel danger que la trachéotomie joue un rôle important dans son traitement Un faible écart à la physiologie respiratoire normale peut être sans inconvénient chez l'adulte alors que, chez le nouveau-né ou le jeune enfant, cet écart peut être désastreux Les auteurs ont étudié 52 cas de trachéotomie pratıquée chez les petits, à l'hôpıtal Sainte-Justine de Montréal, de 1958 à 1960 La trachéotomie s'est avérée efficace et quelquefors dramatıque dans ses résultats chez des enfants cyanosés ou même en état d'asphyxie

Dans la présente série, les complications de l'opération elle-même ont été minımes Des sécrétıons visqueuses peuvent obstruer la canule après l'opération, on évite cette complication par des soins attentifs et une surveillance de tous les instants Une respiration bruyante ou saccadée est un signe prémoniteur de troubles respiratoires

La trachéotomie est une opération simple et elle rend des services incalculables dans plusieurs complications graves telles que l'obstruction bronchique, la compression de la trachée, l'cedème du larynx et la paralysie des muscles respuratorres Les cliniciens devraient être au counant de son efficacité, et ils devraient être prêts à l'utılıser sans hésitation lorsqu'elle est indıquée

\section{REFERENCES}

1 MeLiCE, $P$ Indications and Comphications of Tracheotomy in Acute Laryngitus in Children Acta Pedat Belg 17 5-17 (1963)

2 Dugan, D J \& SAmson, P C Tracheostomy Present Day Indications and Technics Am J Surg $106 \quad 290-306$ (1963)

3 Apgar, $V$ Proposal for New Method of Evaluation of Newborn Infant Anesth \& Analg 32 260-267 (1953)

4 AREY, H $M$ \& AREY, J B Respiratory Disorders of Newborn Infants Correlation of Clinical and Pathological Observations Pediat Clin N Amer 53-72 (Feb 1957)

5 Arkins, J P Current Uthlization of Tracheotorny as a Therapeutic Measure A Review of the Literature and an Analysis of 526 Cases Laryngoscope 70 1672-1690 (1960)

6 Cawthorne, T, Hewlett, A B, \& RANGer, D Discussion Tracheostomy Today Proc Roy Soc Med 52 403-409 (1959)

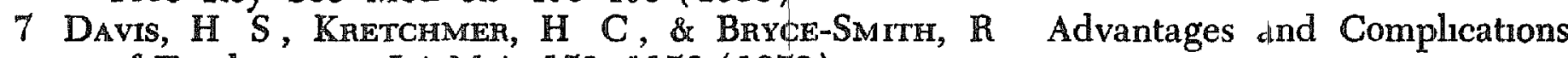
of Tracheotomy JAMA $153 \quad 1156$ (1953)

8 De SANCtis, A G \& VARGA, C Handbool of Pediatric Medical Emergencies St Lours C V Mosby (1951)

9 Diamant, $H$, Kinnman, J \& Ormian, L Decannulation Difficulties in Tracheotomized Children Acta Otolaryngol (Stockholm), Suppl 158 39-42 (1960)

10 Dudley, $H$ A, BaKer, $L$ W, \& ANDErson, W A The Place of Bronchoscopy and Tracheostomy in General Surgical Patients J Roy Coll Surg Edmburgh 7 121-127 (1962)

11 Harrus, L H \& Houston, J Tracheotomy for Acute Respuratory Infections in Emphysema Lancet al $1170-1172$ (1961)

12 HewletT, A B \& Ranger, D Tracheostomy Postgrad Med J 37 18-21 (1961)

13 JACrson, C \&r JACisson, C L Diseases and Injuries of the Larynx New York Macmillan (1942)

14 MATHEson, N A et al The Management of a Tracheostomy Lancet in 31-32 (1963)

15 Landing, B H Anomalies of the Resputatory Tract Pedrat Clin N Amer 73-102 (Feb 1957)

16 Mruter, H C Chnical Evaluation of Respiratory Function in Newborn Infants Pedsat Cln N Amer 17-26 (Feb 1957) 
17 - Studies of Respiratory Insufficiency in Newborn Infants Pediatrics $20 \quad 817-826$ (1957)

18 Nesson, W E Textbook of Pediatrics, 7th ed Philadelphia and London N B Saunders (1959)

19 Fearon, B Acute Laryngo-tracheobronchitıs in Infancy and Childhood Pediat Clin. N Amer 9 1095-1112 (1962)

20 Rearion, H S Blood Chemical Deviations in Respiratory Disorders of the Immediate Postnatal Period Pediat Clin N Amer 3-16 (Feb 1957).

21 SrolnIK, E M \& Fornatoo, E J Tracheotomy Its Present Day Application Laryngoscope $68 \quad 32-47$ (1958)

22 Smrri, C A The Physiology of the Newborn Infant, Brd ed Springfield, Ill $\mathbf{C}$ Thomas (1959) 